\title{
Downslope windstorm in Iceland - WRF/MM5 model comparison
}

\author{
Ó. Rögnvaldsson ${ }^{1,2}$, J.-W. Bao ${ }^{3}$, H. Ágústsson ${ }^{1,4}$, and H. Ólafsson ${ }^{4,5, *}$ \\ ${ }^{1}$ Institute for Meteorological Research, Reykjavík, Iceland \\ ${ }^{2}$ University of Bergen - UiB, Bergen, Norway \\ ${ }^{3}$ NOAA/ESRL, Boulder, USA \\ ${ }^{4}$ University of Iceland, Reykjavík, Iceland \\ ${ }^{5}$ Icelandic Meteorological Office, Reykjavík, Iceland \\ * now at: Bergen school of meteorology, Geophysical Institute UiB, Norway
}

Received: 1 February 2008 - Published in Atmos. Chem. Phys. Discuss.: 1 April 2008

Revised: 8 December 2010 - Accepted: 20 December 2010 - Published: 5 January 2011

\begin{abstract}
A severe windstorm downstream of Mt. Öræfajökull in Southeast Iceland is simulated on a grid of $1 \mathrm{~km}$ horizontal resolution by using the PSU/NCAR MM5 model and the Advanced Research WRF model. Both models are run with a new, two equation planetary boundary layer (PBL) scheme as well as the ETA/MYJ PBL schemes. The storm is also simulated using six different micro-physics schemes in combination with the MYJ PBL scheme in WRF, as well as one "dry" run. Output from a $3 \mathrm{~km}$ MM5 domain simulation is used to initialise and drive both the $1 \mathrm{~km}$ MM5 and WRF simulations. Both models capture gravity-wave breaking over Mt. Öræfajökull, while the vertical structure of the lee wave differs between the two models and the PBL schemes. The WRF simulated downslope winds, using both the MYJ and 2EQ PBL schemes, are in good agreement with the strength of the observed downslope windstorm. The MM5 simulated surface winds, with the new two equation model, are in better agreement to observations than when using the ETA scheme. Micro-physics processes are shown to play an important role in the formation of downslope windstorms and a correctly simulated moisture distribution is decisive for a successful windstorm prediction. Of the microphysics schemes tested, only the Thompson scheme captures the downslope windstorm.
\end{abstract}

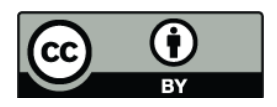

Correspondence to: Ó. Rögnvaldsson (or@belgingur.is)

\section{Introduction}

Iceland is a mountainous island located in the middle of the North Atlantic Ocean in the northern part of the storm track. Due to this, the climate and weather of Iceland are largely governed by the interaction of orography and extra-tropical cyclones. This interaction can be in the form of cold air damming by mountains or warm downslope descent. The atmosphere-mountain interaction can also cause local acceleration of the airflow or a forced ascending motion, causing extreme precipitation. As a result of this interaction, downslope windstorms are quite common in Iceland.

Mountain waves and downslope windstorms have long been a target of research campaigns as well as theoretical and numerical researches. Such windstorms are generally associated with vertically propagating gravity waves in the troposphere. Favourable large-scale flow conditions for the generation of downslope windstorms include elements such as strong low-level winds and strong static stability at low levels. A reverse vertical windshear, as described in Smith (1985), may contribute to downslope windstorm through trapping of wave energy, while a positive vertical windshear may also act positively through amplification of gravity waves (see review by Durran, 1990). The prime objective of the T-REX (Terrain-induced Rotor EXperiment) campaign (Grubišić et al., 2008) in Sierra Nevada was on observations of mountain waves, rotor flow and low- and upper-level turbulence. This was done by means of ground-based observations and state of the art remote sensors and airborne observing systems. Recently, a number of papers based on the observations of T-REX have emerged, e.g. Jiang and Doyle

Published by Copernicus Publications on behalf of the European Geosciences Union. 
(2009) which investigates the impact of moisture on gravity wave activity. One of the main conclusion of the study is that waves are generally weakened by high moisture near mountain top level. Idealised cases of downslope windstorms, and the associated gravity wave activity, as well as real cases of downslope winds in many part of the world have been studied by many authors. The real flow cases include the celebrated 11 January 1972 Boulder windstorm (e.g. Doyle et al., 2000 and ref. therein), downslope windstorms in the Dinaric Alps (e.g. Smith, 1987; Belǔsić and Klaić, 2004; Belǔsić et al., 2004 and ref. therein), windstorms in Norway in westerly flow (e.g. Grønås and Sandvik, 1999; Doyle and Shapiro, 2000; Sandvik and Hartsveit, 2005) and Greenland windstorms in westerly flow (Rögnvaldsson and Ólafsson, 2003; Doyle et al., 2005) as well as easterly flow (Ólafsson and Ágústsson, 2006; Ólafsson and Ágústsson, 2009).

Research on Icelandic downslope windstorms was quite limited until recent studies by Ágústsson and Ólafsson (2007), Ólafsson and Ágústsson (2007) (hereafter ÓÁ-07), and Ágústsson and Ólafsson (2010). Yet the most violent winds in Iceland are in many if not most cases immediately downstream of mountains. One such windstorm hit Freysnes, SE-Iceland, on the morning of 16 September 2004. The windstorm was quite well forecasted in the region by the operational HRAS-system (Ólafsson et al., 2006), which at that time ran the MM5 model (Grell et al., 1995) at a $9 \mathrm{~km}$ horizontal resolution. Locally, the winds became however stronger than the direct model output indicated. Immediately downstream of the ice-covered Öræfajökull mountain (2110 m.a.s.l.) structural damage occurred, including a hotel that lost its roof. This windstorm was investigated in the ÓÁ-07 paper by utilising the MM5 numerical weather prediction model at high resolution and by analysing available observations. The ÓÁ-07 study revealed a flow structure characterized by a stable airmass at mountain level and a reverse vertical windshear in the lower to middle troposphere, leading to the generation and breaking of gravity waves over the mountain. The surface flow was however anomalously warm. These characteristics led to the suggestion that the Freysnes windstorm might be used as a generic name for a warm version of the bora windstorms. The Freysnes case featured at the same time strong downslope and corner winds (i.e. flow speed-up at the southern edge of Mt. Öræfajökull), underlining the fact that simple linear and even non-linear theories of uniform flows might indeed be very different from conditions in the real atmosphere. The downslope windspeed simulated by ÓÁ-07 was considerably underestimated compared to observations. The authors suggested that this might be due to too rapid deceleration of the simulated flow once it had reached the lowland, pointing out the fact that horizontal extension of downslope storms is quite sensitive to both numerical dissipation and advection as well as numerical representation of subgrid processes such as turbulence or eddy viscousity.
The objective of this study is to investigate the differences in the simulated dynamics of the downslope windstorm that are caused by the differences in the dynamical cores (including numerics) of two mesoscale models (MM5 and WRF). A further objective is to investigate the sensitivity of the simulated downslope windstorm to different micro-physics schemes available in the WRF model. This is of importance for operational numerical weather forecasts in complex orography. Especially, in light of ever increasing availability of cheap computational power, high resolution simulations are becoming more common. To study this sensitivity, ten simulations are carried out and compared for the same event as studied in ÓÁ-07. This is done by using two mesoscale models: version 3-7-3 of MM5 and version 2.2 of the Advanced Research WRF model (Skamarock et al., 2005), hereafter called WRF, and two different PBL schemes, the current ETA/MYJ planetary boundary layer model (Mellor and Yamada, 1982; Janjić, 1994, 2001) and a new two equation model (Bao et al., 2008). To investigate the impact of cloud micro-physics on the simulated windstorm, five additional simulations are done with the WRF model using different micro-physics schemes in combination with the MYJ planetary boundary layer scheme, as well as a "dry" run without any micro-physics scheme. The output from the $3 \mathrm{~km}$ domain of the simulation presented in ÓÁ-07 is used to initialise and drive all model simulations on a grid of $1 \mathrm{~km}$ horizontal resolution and 40 vertical layers with the model top at $100 \mathrm{hPa}$. Both the MM5 and WRF models are configured in as similar way as possible. Comparisons of the simulations are made using observed surface winds, temperature and precipitation.

This paper is structured as follows: in the next section we describe the synoptic overview and list the available observational data in the area. The experimental setup is described in Sect. 3. The results are presented in Sect. 4. Discussions are presented in Sect. 5, followed by concluding remarks.

\section{Synoptic overview and available observational data}

Figure 1 shows the mean sea level pressure, the geopotential height at $500 \mathrm{hPa}$ and the temperature at $850 \mathrm{hPa}$ at the time when wind gusts greater than $50 \mathrm{~ms}^{-1}$ were observed at the Skaftafell and Öræfi weather stations (see Fig. 2 for location of the stations). At the surface, the geostrophic winds are from the ESE, while over land the surface winds are from the ENE or NE. At $500 \mathrm{hPa}$, the flow is relatively weak (20$25 \mathrm{~ms}^{-1}$ ) and the wind direction is from the SSE. There is a sector of warm air at $850 \mathrm{hPa}$ stretching from Ireland towards S-Iceland. In the early morning of 16 September, the observed 2-m temperature at Skaftafell exceeds $15^{\circ}$ which is about $7^{\circ}$ above the seasonal average. The geostrophic wind at the surface is greater than $30 \mathrm{~ms}^{-1}$ and there is a directional and a reverse (negative) vertical wind shear in the lower part of the troposphere (ÓÁ-07). Figure 2 shows the domain setup of the MM5 and WRF simulations as 
well as local orography and the location of automatic meteorological stations. These are Skaftafell (SKAFT), Öræfi (ORAFI), Ingólfshöfði (INGOL), Fagurhólsmýri (FAGHO) and Kvísker (KVISK). Surface wind speed and direction, gusts and temperature are all measured at these stations. At stations SKAFT, FAGHO and KVISK, accumulated precipitation is measured once to twice daily. The straight line crossing Mt. Öræfajökull shows the location of the cross sections shown in Fig. 6. Hvannadalshnjúkur, the highest peak of Mt. Öræfajökull, exceeds $2100 \mathrm{~m}$ above sea level while the altitude of the Öræfajökull plateau is between 1900 and $2000 \mathrm{~m}$ a.s.l.

\section{Experimental setup}

Initial and boundary data are derived from model simulations described in ÓÁ-07. In the ÓÁ-07 study, atmospheric flow was investigated using version 3-6-1 of the MM5 model (Grell et al., 1995). The subgrid turbulence was parameterized using the ETA PBL scheme (Janjić, 1994). The ÓÁ-07 simulation was run with the Grell cumulus scheme (Grell et al., 1995) and the Reisner2 explicit moisture scheme (Thompson et al., 2004). Radiation was calculated using the CCM2 scheme (Hack et al., 1993). The ÓÁ-07 three domain setup is shown in Fig. 3, the horizontal resolution being 9, 3 and $1 \mathrm{~km}$. The 9 and $3 \mathrm{~km}$ domains are centered over Iceland and they consists of $95 \times 90$ and $196 \times 148$ gridpoints in the horizontal. The $1 \mathrm{~km}$ domain has $175 \times 157$ points and is centered over the southern part of the Vatnajökull ice cap. The calculations employ 40 vertical (full- $\sigma$ ) levels with the model top at $100 \mathrm{hPa}$.

In our experiment we use the ÓÁ-07 model output from the $3 \mathrm{~km}$ domain as initital and boundary data to all our simulations, both with MM5 (version 3-7-3) and WRF (version 2.2). The simulation domain is the same as the $1 \mathrm{~km}$ domain in ÓÁ-07 (cf. Fig. 2 and Fig. 3). At this resolution the Mt. Öræfajökull peak reaches 1920 m a.s.l. The MM5 model control setup (MM5/ETA) is very similar to that in ÓÁ-07 with the exception of a more recent version of the model and the use of the RRTM radiation scheme (Mlawer et al., 1997) instead of the CCM2 scheme. The MM5 model is also run with a new two equation PBL scheme (MM5/2EQ), described in Bao et al. (2008). The two equation model is based on the Mellor-Yamada level 2.5 second-moment closure (MY closure), and consists of two prognositc equations. One for the TKE and the other for the length scale multiplied by twice the TKE. As with the ÓÁ-07 simulation, both MM5 simulations use an upper radiative boundary condition.

For the WRF model (Skamarock et al., 2005) control simulation (WRF/MYJ) we use the Mellor-Yamada-Janjić (Janjić, 1994, 2001) subgrid turbulence scheme. No cumulus scheme is used as opposed to the Grell scheme in the MM5/ETA and MM5/2EQ simulations. An upgraded version of the Reisner2 scheme, the Thompson scheme (Thomp-

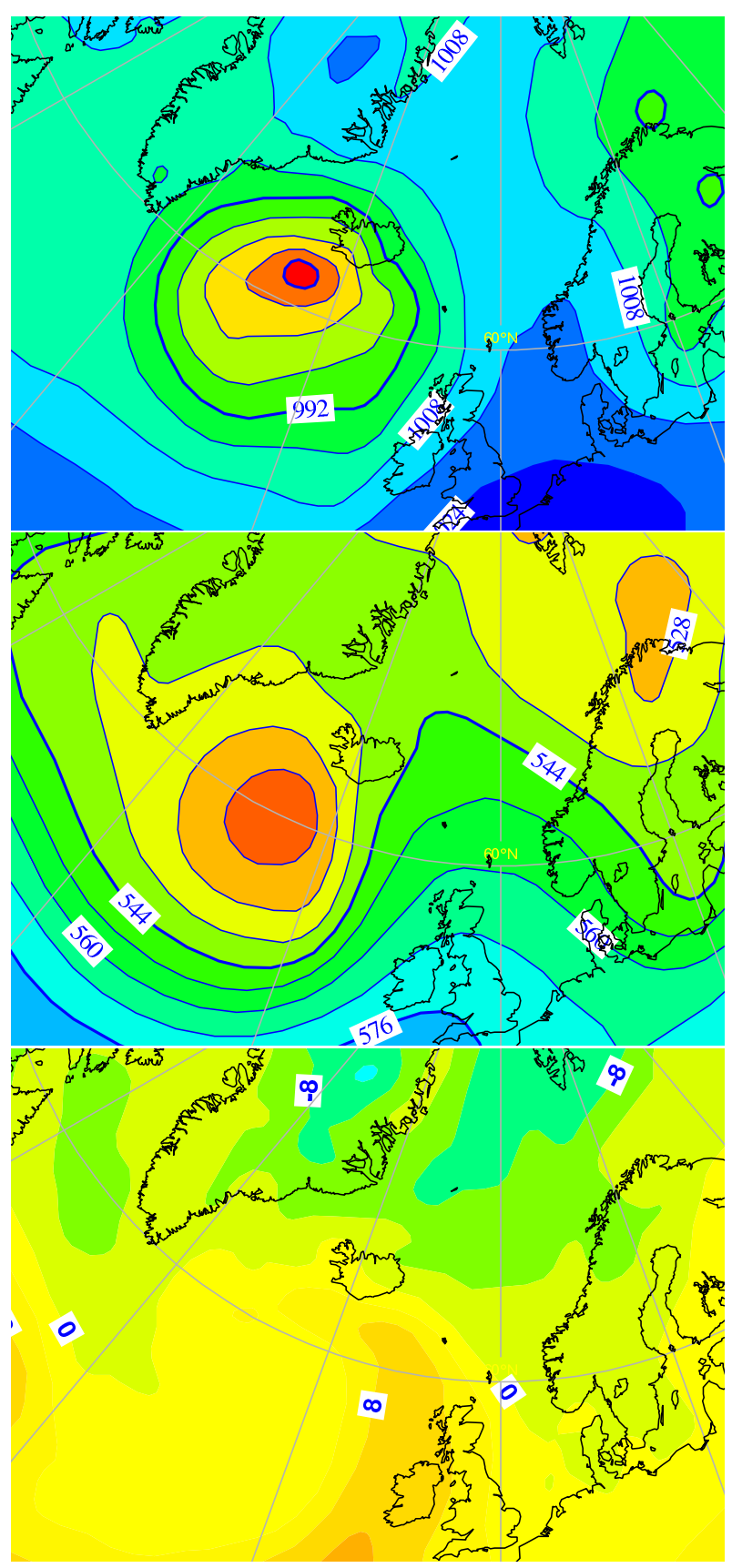

Fig. 1. Mean sea level pressure [hPa] (top), geopotential height at $500 \mathrm{hPa}[\mathrm{m}]$ (middle) and temperature at $850 \mathrm{hPa}\left[^{\circ}\right]$ (bottom) on 16 September 2004 at 06:00 UTC. Based on the operational analysis provided by the ECMWF.

son et al., 2004), is used. Long wave radiation is calculated using the RRTM long wave scheme and short wave radiation is simulated using the Dudhia (1989) scheme ${ }^{1}$ from the MM5 model. As with the MM5 simulations the calculations

\footnotetext{
${ }^{1}$ When the RRTM radiation obtion is chosen in MM5, this is the scheme used to calculate short wave radiation.
} 


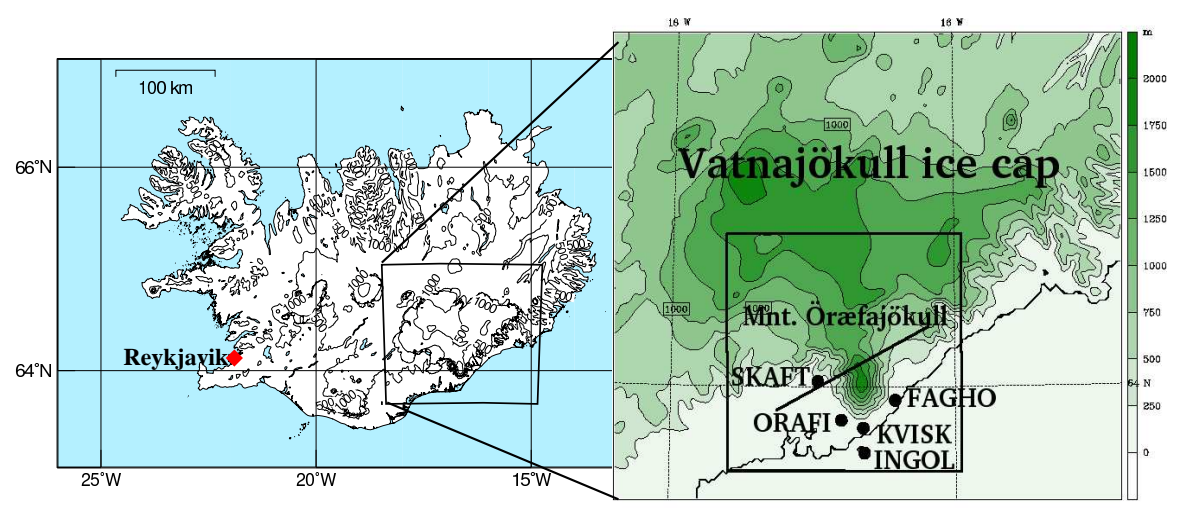

Fig. 2. The $1 \mathrm{~km}$ domain setup of the Vatnajökull ice cap and location of observational sites. The box on the right hand side shows the region of interest around Mt. Öræajökull (cf. Fig. 4). The location of the Freysnes hotel coincides with location SKAFT. The colour scale to the right represents the terrain height.

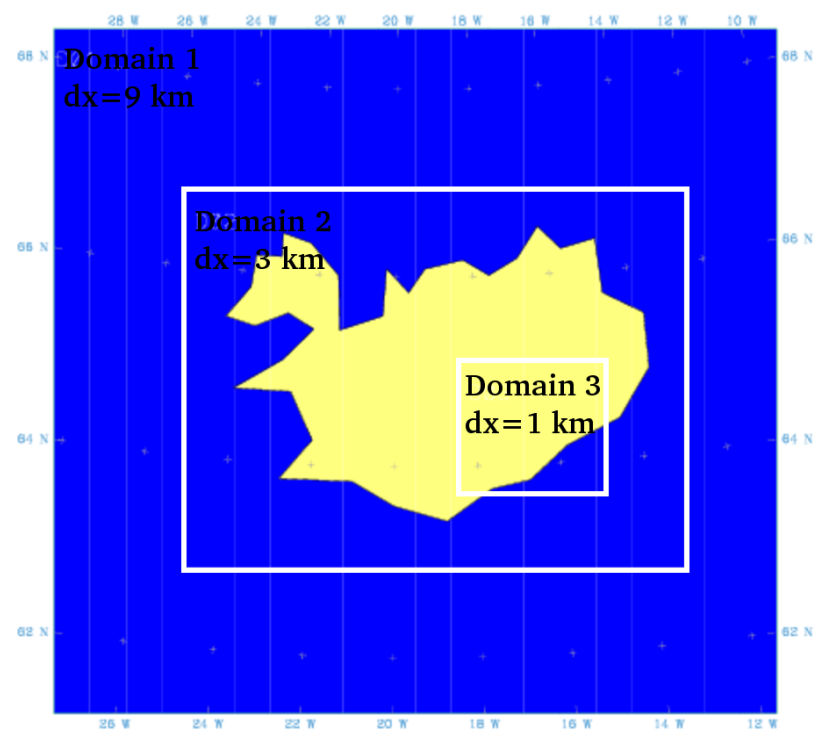

Fig. 3. MM5 domain setup of the ÓÁ-07 experiment, the number of horizontal gridpoints for domains 1,2 and 3 are $95 \times 90,196 \times 148$ and $175 \times 157$, respectively. Domain 3 is the same domain as is used in this experiment. All simulations employ 40 vertical levels.

employ 40 vertical (full- $\eta$ ) levels with the model top at $100 \mathrm{hPa}$. No damping is imposed on the upper boundary, rather, vertical motion is damped to prevent the model from becoming unstable with locally large vertical velocities. This only affects strong updraft cores, so has very little impact on results otherwise. The WRF model was also run with the two equation PBL scheme (called WRF/2EQ).

In order to investigate the impact of various micro-physics schemes on the downslope flow we ran WRF with five different micro-physics schemes in addition to the Thompson scheme. The micro-physics schemes range from the relatively simple two class Kessler (1969) and WSM3 to the more complex WSM5 (a four class scheme without graupel) and the five class WSM6 (Hong and Lim, 2006), Lin et al. (1983) and Thompson et al. (2004) schemes. A detailed description of the WSM3 and WSM5 schemes can be found in Hong et al. (2004). Beside the differences in the micro-physics, the model setup was that of the WRF control simulation (called WRF/MYJ).

Finally, to find whether evaporation, and consequently condensation, might be a relevant factor for the flow dynamics, a "dry" simulation was carried out. This experiment was identical to the control simulation, with the exception that the microphysics and surface fluxes were turned off.

None of the simulations showed any signs of vertically reflected waves from the top of the model.

\section{Results}

\subsection{Model sensitivity to PBL schemes}

\subsubsection{Surface winds, temperature and precipitation}

All MM5 and WRF simulations capture strong winds over the Vatnajökull ice cap (Fig. 4) as well as over the lowlands. In all simulations the flow is decelerated upstream of Mt. Öræfajökull. The simulated near surface wind speed, taken at the lowest half-sigma level (approximately $40 \mathrm{~m}$ a.g.l.), has a maximum immediately downstream of the highest mountain (Mt. Öræfajökull). This maximum does not extend far downstream. There is also a secondary maximum of wind speed emanating from the edge of the same mountain (labeled corner-wind in ÓÁ-07). This secondary maximum extends far downstream. Accumulated precipitation measured at SKAFT, FAGHO and KVISK is compared with simulated precipitation in Table 1. Both models correctly simulate the dry area downstream of Mt. Öræfajökull (station SKAFT). On the windward side (station FAGHO) 

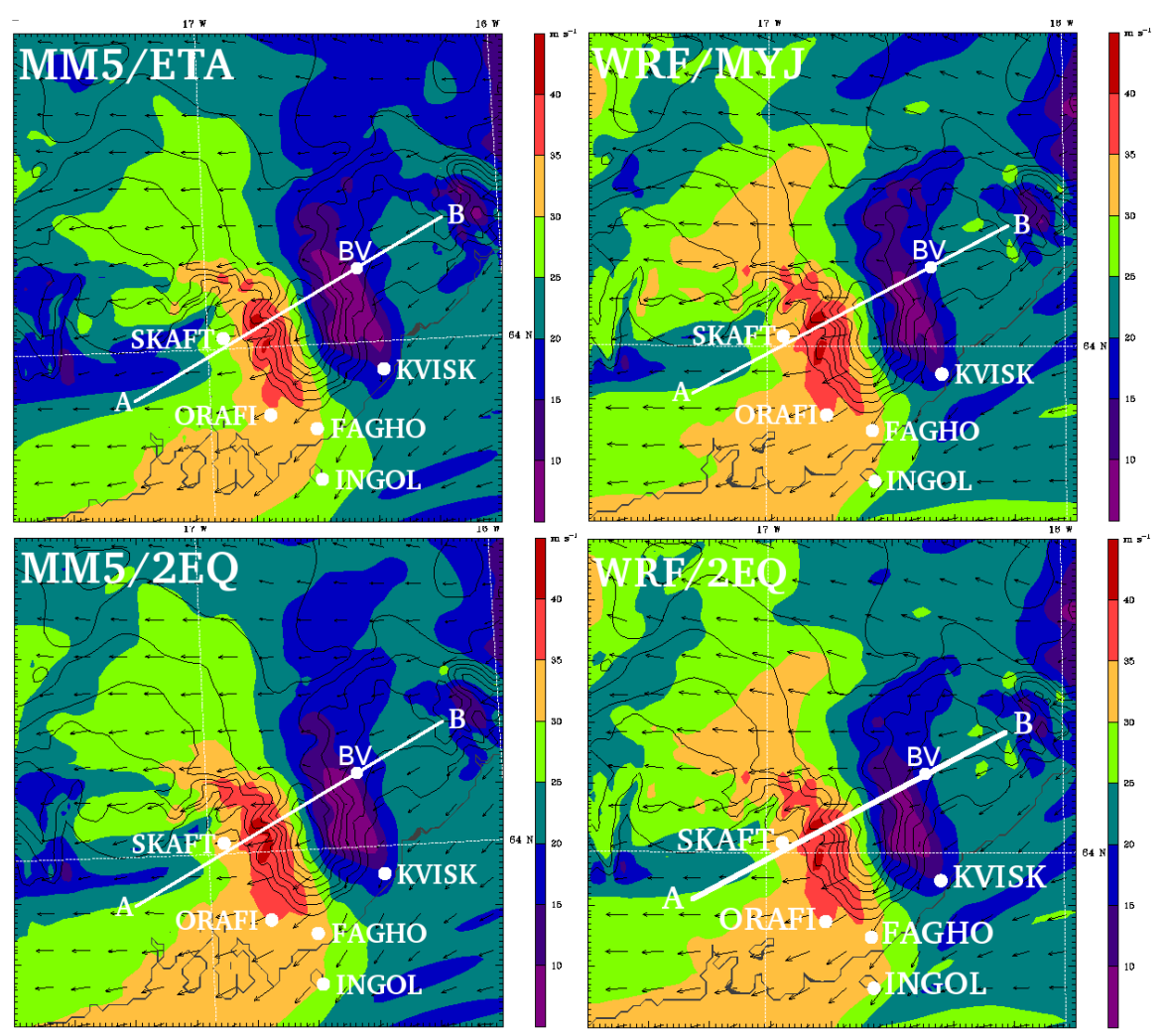

Fig. 4. Zoomed in view of simulated surface wind speed $\left[\mathrm{ms}^{-1}\right]$ at lowest half-sigma level (approximately 40 m a.g.l.) by MM5 (left panels) and WRF (right panels) at 16 September 2004, 06:00 UTC. Top panels show results from the ETA and MYJ boundary layer schemes and the bottom panel shows results using the new two equation PBL model. The letters "BV" show the location of the vertical profile, along which the Brunt-Väisälä frequency in Table 4 is calculated. The upstream distance from point B to the lateral boundaries of the $1 \mathrm{~km}$ domain is approximately $60 \mathrm{~km}$.

Table 1. Observed and simulated accumulated precipitation [mm], between 15 September, 18:00 UTC and 16 September, 09:00 UTC, at stations SKAFT, FAGHO and KVISK.

\begin{tabular}{lr|rr|rr}
\hline \multirow{2}{*}{ Location } & Observed & \multicolumn{2}{|c|}{ MM5 } & \multicolumn{2}{c|}{ WRF } \\
\cline { 3 - 6 } & & ETA & 2EQ & MYJ & 2EQ \\
\hline SKAFT & 0.0 & 0.0 & 0.0 & 0.8 & 0.8 \\
FAGHO & 42.4 & 49.8 & 47.6 & 74.8 & 74.3 \\
KVISK & 59 & 55.5 & 45.9 & 95.0 & 93.0 \\
\hline
\end{tabular}

all four simulations tend to overestimate the precipitation. The overestimation with MM5/ETA and MM5/2EQ is $17 \%$ and $12 \%$, respectively, while the WRF/MYJ and WRF/2EQ simulations overestimate the observed precipitation by approximately $75 \%$. This overestimation can, to some extent, be explained by under catchment of the rain gauges due to strong winds. At location KVISK, the MM5 simulations underestimate the precipitation by $6 \%$ (MM5/ETA) and 22\% (MM5/2EQ) while the WRF model overestimates the precipitation by $61 \%(\mathrm{WRF} / \mathrm{MYJ})$ and $58 \%(\mathrm{WRF} / 2 \mathrm{EQ})$. The precipitation gradient reproduced in the WRF simulations (i.e., more precipitation at KVISK than at FAGHO) is in better agreement with observed gradient than that reproduced in the MM5 simulations. However, the precipitation values in the MM5 simulations are closer to the observed values. With regard to wind speed, there exists a noticeable quantitative difference between the four simulations. Figure 5 shows observed and simulated $10-\mathrm{m}$ wind speed and 2-m temperature at station SKAFT (top) and FAGHO (bottom). At location SKAFT, the WRF simulated downslope winds, using the MYJ and 2EQ PBL schemes, are in good agreement with the strength of the observed downslope windstorm, with the maximum wind speed as great as 29 and $30 \mathrm{~ms}^{-1}$, respectively. The MM5 simulated surface winds, with the new two equation model, are in better agreement to observations than when using the ETA scheme. Surface winds reach $22 \mathrm{~ms}^{-1}$ when using the two equation model whilst the winds in the MM5/ETA simulation only reach about $17 \mathrm{~ms}^{-1}$. Further, the $2-\mathrm{m}$ temperature is captured considerably better by the WRF model than 

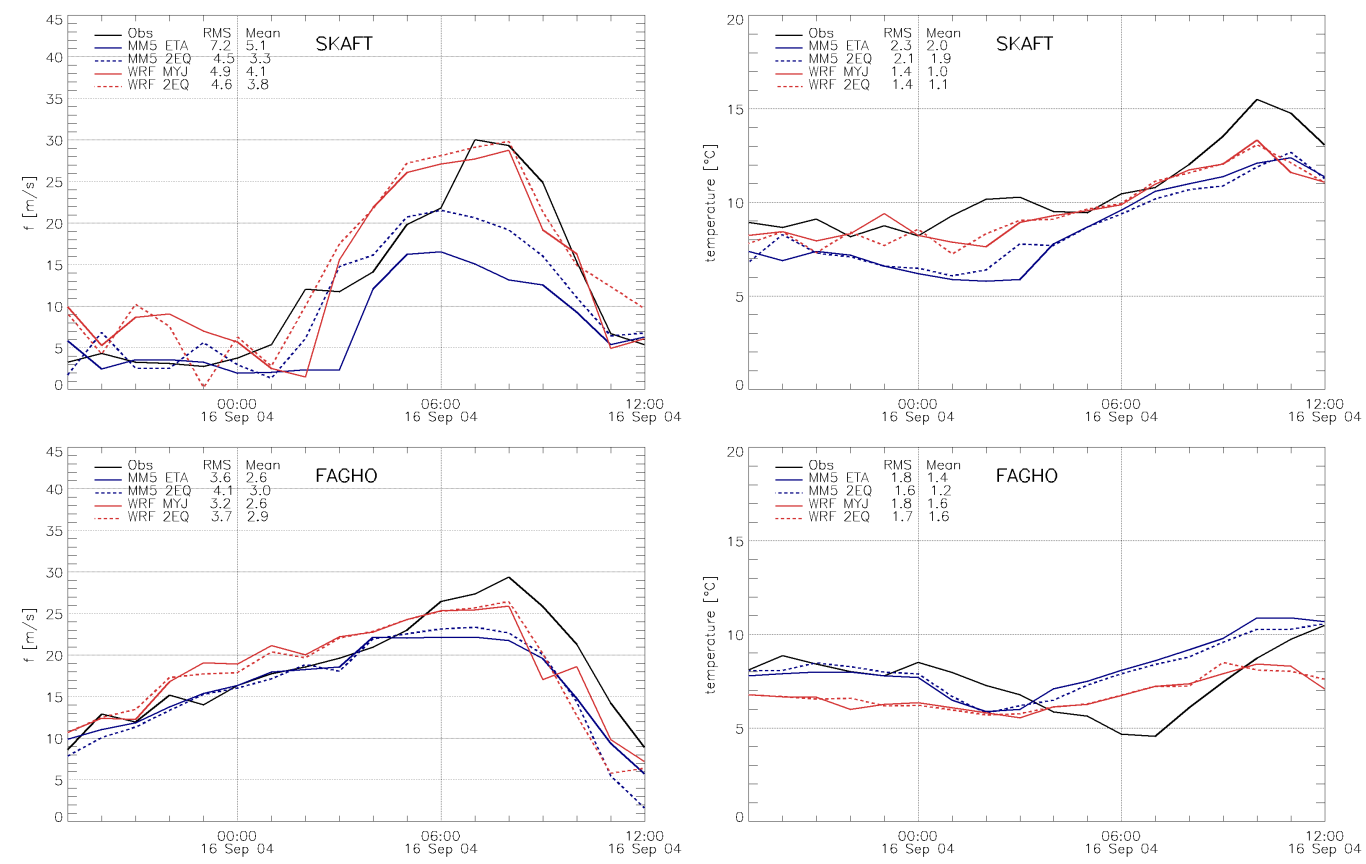

Fig. 5. Observed (solid black) and simulated (solid blue - MM5/ETA, blue dash - MM5/2EQ, solid red - WRF/MYJ, red dash - WRF/2EQ) $10 \mathrm{~m}$ wind speed $\left[\mathrm{ms}^{-1}\right]$ (left) and 2-m temperature $\left[{ }^{\circ}\right]$ (right) at station SKAFT (WMO\# 4172, top row) in the lee of Mt. Öræfajökull and at station FAGHO (bottom row).

by MM5. On average, the MM5 simulated 2-m temperature is $2-3^{\circ}$ colder than measured while the $2-\mathrm{m}$ temperature in WRF is very close to the observed surface temperature. At station FAGHO the MM5 results are very similar, both simulations correctly capture the storm at early stages but start to tail off at 23:00 UTC on 15 September. Consequently, both MM5/ETA and MM5/2EQ underestimate wind from the mountain edge during the peak of the storm and fail to capture the maximum wind strength by 7.5 and $6.5 \mathrm{~ms}^{-1}$, respectively. The WRF/MYJ and WRF/2EQ simulations overestimate the winds during the early stages (i.e. between 22:00 UTC and 05:00 UTC) of the storm by $2-5 \mathrm{~ms}^{-1}$ but underestimate the observed maximum winds $\left(30 \mathrm{~ms}^{-1}\right)$ by 3.5 and $3 \mathrm{~ms}^{-1}$, respectively. All four runs show similar skills simulating surface temperature at FAGHO with RMS errors ranging from $1.6^{\circ}$ (MM5/2EQ) to $1.8^{\circ}$ (MM5/ETA and WRF/MYJ). However, at the other three stations (ORAFI, KVISK, and INGOL), the differences in temperature between the four simulations are small (not shown). At station ORAFI both WRF simulations overestimate the mean wind by approximately $5 \mathrm{~ms}^{-1}$ while MM5/ETA captures the wind field correctly. The MM5/2EQ simulation gives wind speed values that lie between the WRF and MM5/ETA simulated values, the wind speed being $2-3 \mathrm{~ms}^{-1}$ higher than observed. At KVISK both models perform similarly, the MM5 underestimates the winds slightly while WRF slightly overestimates them. With the current model configuration, sta- tion INGOL is off-shore in both models. Hence, observed and simulated fields can not be compared in a logical manner. Table 2 lists the root mean square and mean errors in simulated wind speed at all five stations during the simulation period.

\subsubsection{Wave structure}

Figure 6 shows a cross section along line AB (cf. Fig. 4) from the four simulations at 06:00 UTC 16 September. In both MM5 simulations, the distribution of turbulent kinetic energy (TKE) shows that there is very strong mountain wave breaking between approximately 800 and $650 \mathrm{hPa}$ and very little wave activity above $500 \mathrm{hPa}$. There is intense turbulence below $700 \mathrm{hPa}$ associated with the wave breaking. At the surface, there is also a layer of high TKE. In spite of common features the MM5/ETA and MM5/2EQ simulations reveal important differences in the wave and TKE structure. Between 18:00 UTC and 00:00 UTC on 15 September, there is stronger TKE between 900 and $700 \mathrm{hPa}$ in the MM5/ETA simulation downslope of the mountain than in the MM5/2EQ simulation. The wave structure however remains similar. Few hours later, between 01:00 UTC and 03:00 UTC on 16 September, the wave penetrates considerably deeper in the MM5/2EQ simulation. During this time interval simulated surface wind speed at location SKAFT increases sharply from 3 to $15 \mathrm{~ms}^{-1}$ in MM5/2EQ whilst staying calm in the MM5/ETA simulation. This compares favourably with 
Table 2. Root mean square (RMS) and mean errors $\left[\mathrm{ms}^{-1}\right]$ of simulated wind speed at stations SKAFT, ORAFI, INGOL, FAGHO and KVISK.

\begin{tabular}{l|rr|rr|rr|rr|}
\hline \multirow{2}{*}{ Location } & \multicolumn{2}{|c|}{ MM5/ETA } & \multicolumn{2}{c|}{ MM5/2EQ } & \multicolumn{2}{c|}{ WRF/MYJ } & \multicolumn{2}{c|}{ WRF/2EQ } \\
\cline { 2 - 9 } & RMS & Mean & RMS & Mean & RMS & Mean & RMS & Mean \\
\hline SKAFT & 7.2 & 5.1 & 4.5 & 3.3 & 4.9 & 4.1 & 4.6 & 3.8 \\
ORAFI & 2.2 & 1.9 & 4.8 & 3.8 & 6.8 & 6.0 & 6.6 & 5.8 \\
INGOL & 9.3 & 7.4 & 9.0 & 6.9 & 8.0 & 6.6 & 7.8 & 6.5 \\
FAGHO & 3.6 & 2.6 & 4.1 & 3.0 & 3.2 & 2.6 & 3.7 & 2.9 \\
KVISK & 2.1 & 1.6 & 3.2 & 2.6 & 3.0 & 2.4 & 3.0 & 2.4 \\
\hline
\end{tabular}
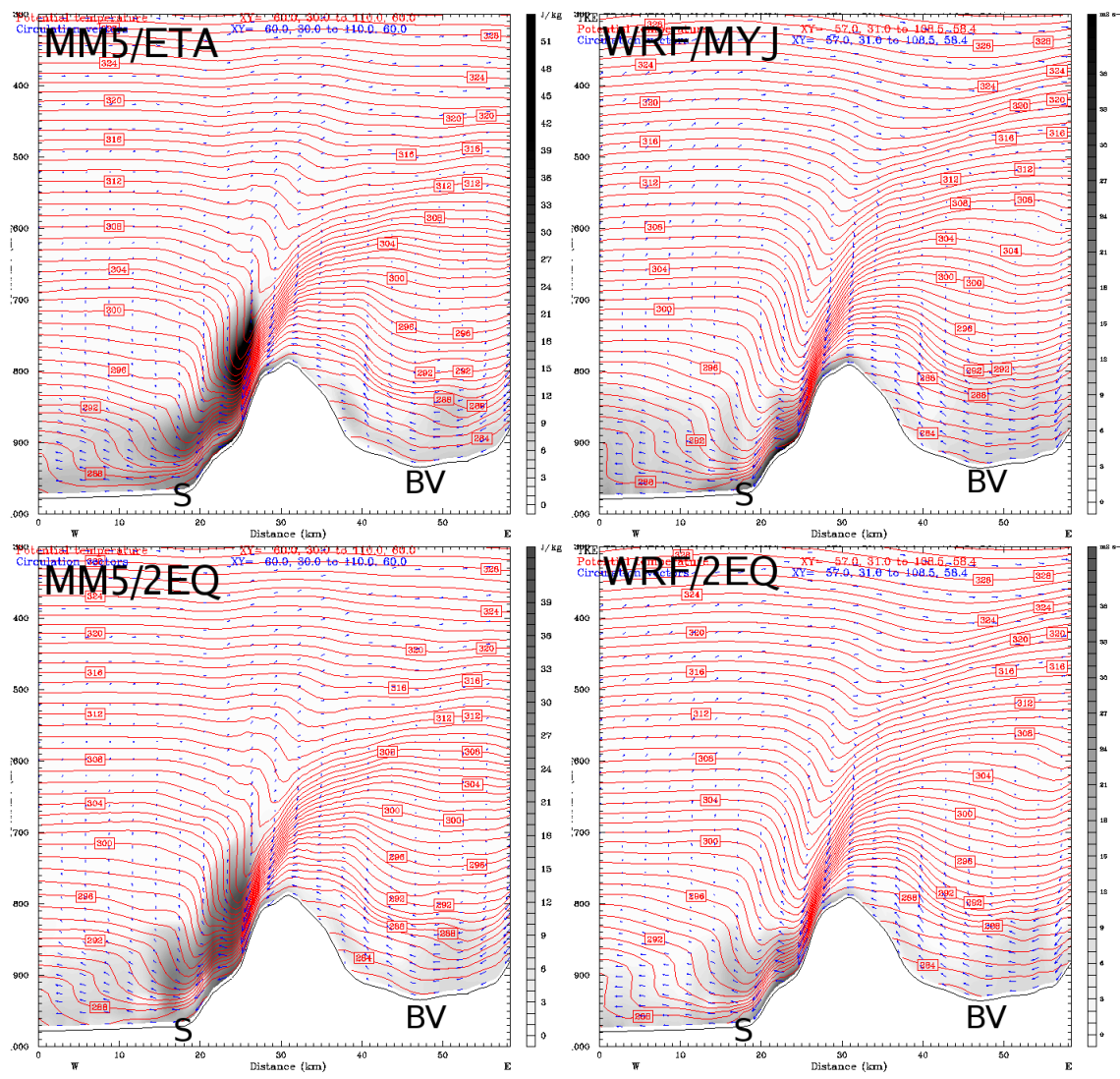

Fig. 6. Cross section along line $\mathrm{AB}$ (cf. Fig. 4) showing potential temperature (red lines) [K], wind along the cross section (blue arrows) $\left[\mathrm{ms}^{-1}\right]$ and turbulent kinetic energy (TKE) [J/kg] for MM5 (left panels) and WRF (right panels) at 16 September 2004, 06:00 UTC. Top panels show results from the ETA and MYJ boundary layer schemes and the bottom panel shows results using the new two equation PBL model. The letter "S" indicates the location of SKAFT and "BV" shows the location of the vertical profile, along which the Brunt-Väisälä frequency in Table 4 is calculated.

observations as wind speed at SKAFT increased from 5 to $12 \mathrm{~ms}^{-1}$ during this period. At 03:00 UTC the TKE in the lee of the mountain is confined below the $T_{\theta}=286 \mathrm{~K}$ isoline in the MM5/2EQ simulation but below the $T_{\theta}=289 \mathrm{~K}$ isoline in the MM5/ETA simulation. During the peak of the windstorm, between 06:00 UTC and 09:00 UTC on 16 September, there is stronger TKE aloft in the lee of the mountain in the
MM5/2EQ simulation but the wave structure is now again very similar. After 09:00 UTC there is very little difference between the two MM5 simulations.

The wave structure simulated with the two WRF variations remains similar for the whole period. The same can not be said about the TKE distribution and intensity. The onset of strong TKE production is evident at 22:00 UTC on 
15 September in WRF/MYJ and an hour later in WRF/2EQ. The maximum TKE in WRF/2EQ, between 23:00 UTC 15 September and 02:00 UTC 16 September, is confined to a narrow band (approximately $5 \mathrm{~km}$ wide) directly in the lee of the mountain between 750 and $900 \mathrm{hPa}$ height. The TKE intensity in this region is about twice that simulated by the WRF/MYJ during the same time interval. The width of the TKE distribution in WRF/MYJ is approximately twice that of WRF/2EQ and the wave penetrates sligthly deeper (typically $10-20 \mathrm{hPa}$ ). For the remainder of the simulation period both schemes produce TKE of the same order of magnitude and with very similar distribution. Only during the peak of the simulated surface winds, 08:00 UTC 16 September, WRF/2EQ simulates greater values (approximately 20\%) of TKE in the lee of the mountain but the upward reach is not as great as in the WRF/MYJ simulation $(700 \mathrm{hPa}$ vs. $650 \mathrm{hPa})$.

The wave breaking, simulated by the WRF model, differs from the wave breaking simulated by MM5. Particularly, the WRF simulated wave breaking is much weaker than that in the MM5 simulations. Interestingly, there is high TKE production at the surface in the WRF simulations as in the MM5 simulations. During hours 01:00 UTC and 03:00 UTC, downward penetration of the simulated wavestructure in the lee of the mountain is similar between the MM5/2EQ and the two WRF simulations. As with the MM5/2EQ simulation, the simulated surface wind speed at SKAFT increases significantly during this time. For WRF/MYJ the winds change from 2.5 to $15.5 \mathrm{~ms}^{-1}$ and the WRF/2EQ wind speed increases from 3 to $17.5 \mathrm{~ms}^{-1}$. Observed wind speed changes from 5 to $12 \mathrm{~ms}^{-1}$ over this period.

\subsection{Impact of micro-physics on the WRF/MYJ simulations}

\subsubsection{Precipitation}

Accumulated precipitation as simulated using the various micro-physics schemes is shown in Fig. 7. The effects of increased complexity within the three WSM schemes are evident. In the simulation using the simplest three class scheme (top right) the precipitation maximum is on the lee side of the mountain. As the effects of ice and snow hydro-meteors is taken into account in WSM5 (middle left), the upslope and lee side precipitation are of the same order of magnitude. In WSM6 (bottom left), where the effects of graupel are included, the maximum of simulated precipitation has shifted to the upwind slopes of the mountain. The downslope precipitation maximum is not seen in the relatively simple Kessler scheme. Interestingly, the precipitation pattern, using the Kessler scheme, is similar to that of the more complex Lin et al., WSM6 and Thompson schemes, although the simulated maximum is greater. Table 3 compares observed precipitation to simulated precipitation using the six micro-physics schemes. In general, all schemes overestimate the downslope precipitation at location SKAFT, with the exception of
Table 3. Observed and simulated accumulated precipitation [mm], between 15 September, 18:00 UTC and 16 September, 09:00 UTC, at stations SKAFT, FAGHO and KVISK using various microphysics schemes in combination with the MYJ PBL scheme in WRF.

\begin{tabular}{lrrr}
\hline & SKAFT & FAGHO & KVISK \\
\hline Observed & 0.0 & 42.4 & 59 \\
Kessler & 30.4 & 126.5 & 149.4 \\
WSM3 & 9.6 & 70.0 & 57.8 \\
WSM5 & 19.9 & 63.5 & 52.9 \\
Lin et al. & 13.8 & 148.0 & 128.3 \\
WSM6 & 8.7 & 110.7 & 93.2 \\
Thompson & 0.8 & 74.8 & 95.0 \\
\hline
\end{tabular}

the Thompson scheme. At FAGHO, the schemes overestimate the precipitation by a factor of 1.6 (WSM5) to 2.7 (Lin et al.). During the accumulation period observed wind speed at FAGHO ranged from $10 \mathrm{~ms}^{-1}$ at 18:00 UTC 15 September to $30 \mathrm{~ms}^{-1}$ at 09:00 UTC 16 September. During such high wind speeds it can be assumed that a considerable proportion of the precipitation will not be measured by a conventional rain gauge as that at FAGHO. The observed wind speed at KVISK is considerably lower during the accumulation period, ranging from $4 \mathrm{~ms}^{-1}$ to $15 \mathrm{~ms}^{-1}$. As observed wind speed is less at KVISK than at FAGHO observations give a greater underestimation of true ground precipitation at FAGHO than at KVISK. Consequently, it can be expected that simulated precipitation at KVISK will be in better agreement with observed precipitation than at FAGHO.

\subsubsection{Surface winds and temperature}

The intensity of the simulated downslope windstorm is not only sensitive to the PBL schemes but also to the cloud micro-physics schemes.

Figure 8 shows the variation of the WRF/MYJ simulated surface wind speed (left) and temperature (right) at SKAFT that is caused by using various options of the cloud microphysics schemes. It is seen that there is a significant variation in the simulated maximum surface wind speed corresponding the different cloud micro-physics schemes, and the Thompson scheme appears to produce the result in the best agreement with the observation. The surface temperature is also best simulated with the Thompson scheme, being very close to observed temperature during the peak of the storm (04:00 UTC to 08:00 UTC on 16 September). During this period the WRF/MYJ model, using other micro-physic parameterisations, overestimates the surface temperature at Skaftafell by $1-3^{\circ}$. However, the model does not capture the observed temperature maximum $\left(15.5^{\circ}\right)$ at 10:00 UTC, but the Thompson scheme produces results that are closest to the observed values. 

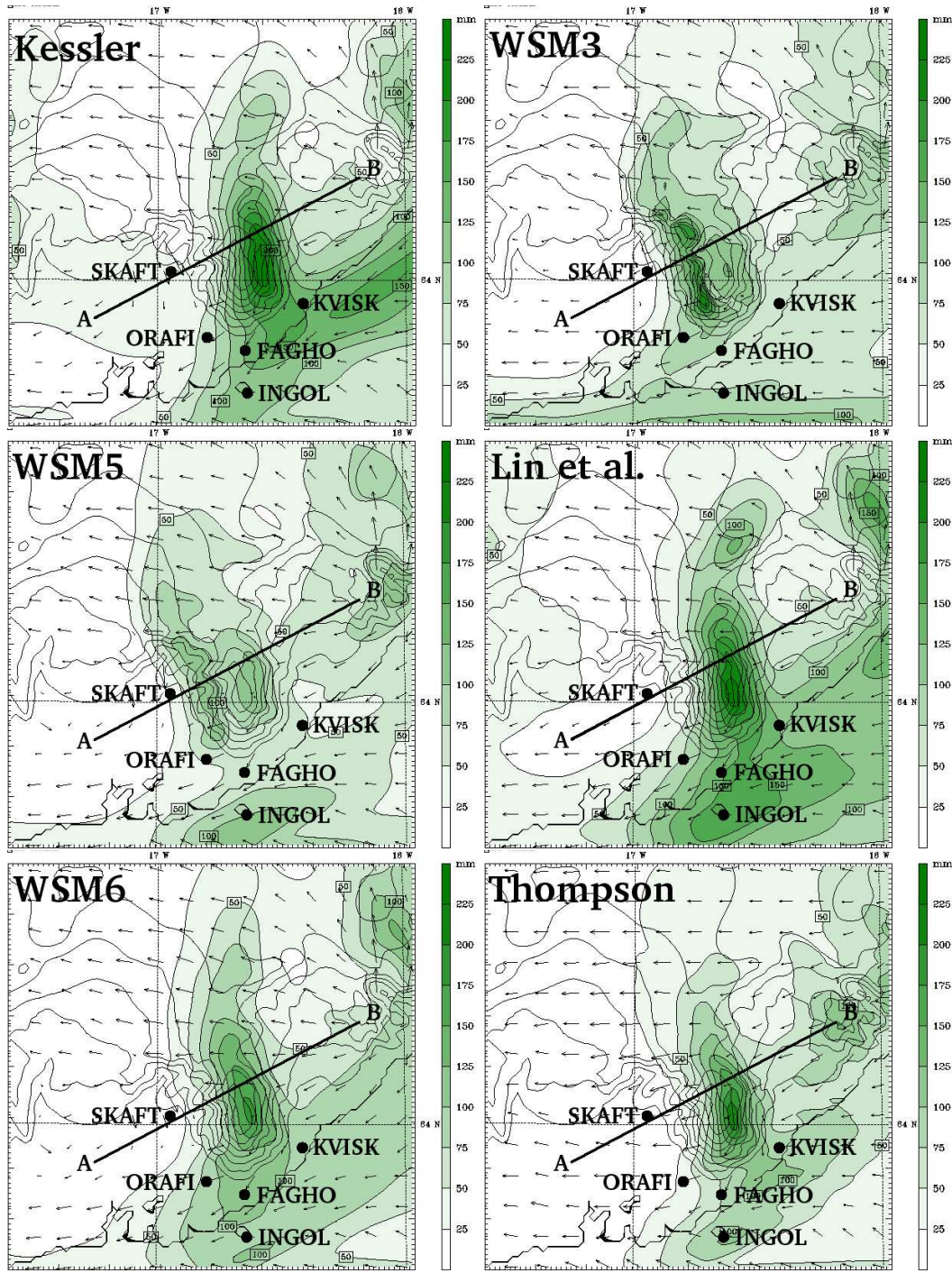

Fig. 7. Accumulated precipitation between 18:00 UTC 15 September and 09:00 UTC 16 September 2004. micro-physics schemes are, from top left to bottom right: Kessler, WSM3, WSM5, Lin et al., WSM6 and Thompson.
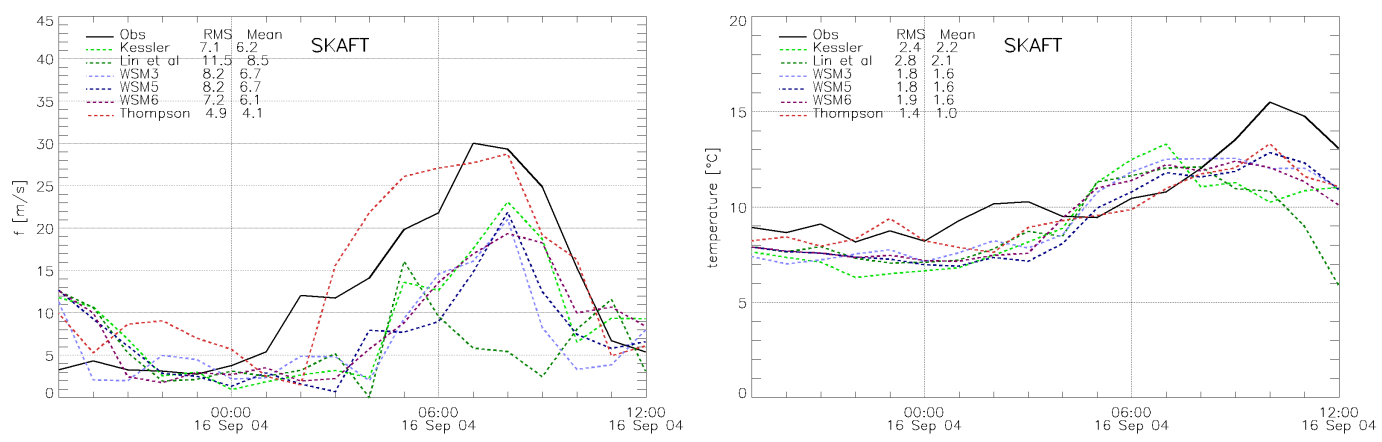

Fig. 8. Observed (solid black) and simulated (dashed) $10 \mathrm{~m}$ wind speed $\left[\mathrm{ms}^{-1}\right]\left(\right.$ left) and $2-\mathrm{m}$ temperature $\left[{ }^{\circ}\right]$ (right) at station Skaftafell (WMO\# 4172 - SKAFT) in the lee of Mt. Öræfajökull. Various colours represent various micro-physic parameterisations within the WRF model: Light green - Kessler, dark green - Lin et al., light blue - WSM3, dark blue - WSM5, purple - WSM6 and red - Thompson scheme. 


\subsubsection{Hydro-meteors}

There is a distinct difference between the Thompson scheme and the other five schemes when it comes to simulated surface wind speeds in the wake of Mt. Öræfajökull. The simulated wind speed is considerably less than observed wind speed at location SKAFT in all micro-physics schemes but the Thompson scheme. The six micro-physics schemes do not differ much in either distribution nor quantity of the water vapour mixing ratio. All models reveal wet cores below $700 \mathrm{hPa}$ height on both sides of Mt. Öræfajökull. Over the mountain, where the air is descending, the water vapour mixing ratio is less than in the humid low level cores (not shown). Figure 9 shows a cross section along line AB (cf. Fig. 4) for the various micro-physics scheme. The simple three class schemes (i.e. Kessler and WSM3) simulate distinctly less cloud water than the other four micro-physics schemes (i.e. WSM5, Lin et al., WSM6, and Thompson). The cloud water is confined to a shallow (below $700 \mathrm{hPa}$ ) layer on the upslope side of the mountain. In contrast, the WSM5 and WSM6 schemes further simulate cloud water at mountain height (approximately $800 \mathrm{hPa}$ ) in the lee of Mt. Öræfajökull. The simulation done with the Thompson scheme produces a humid high level (between 350 and $700 \mathrm{hPa}$ ) plume on the lee side of the mountain. There are considerable variations in the rain water mixing ratio, both in time and space, in all microphysics schemes. Most noticeably, the Thompson scheme shows the least rain water in the lee of the mountain during the peak of the downslope wind storm. In the simulation of this storm the WSM6 and Lin et al. schemes favoured the formation of graupel to that of snow. This is in contrast to the Thompson scheme which only simulated moderate amounts of graupel between 700 and $850 \mathrm{hPa}$ height, upslope of the mountain. This can clearly be seen in Fig. 10, valid at 09:00 UTC 16 September.

Yet another striking difference between the Thompson scheme and the other micro-physics schemes is the relatively low level (i.e. below $600 \mathrm{hPa}$ ) dryness in the lee of Mt. Öræfajökull (cf. Fig. 11) during the hours of maximum downslope wind speed. The wave activity is further much stronger when simulated with the Thompson scheme than all the other micro-physics schemes. Figure 12 shows a skew-T diagram at location B (cf. Fig. 4) for the Thompson and the WSM6 simulations. It can be seen that the temperature between 750 and $800 \mathrm{hPa}$ in the Thompson scheme is less than in the WSM6 scheme by about $2.5^{\circ}$. The upstream moist static stability at, and above, mountain height (i.e. between 750 and $800 \mathrm{hPa}$ ) is greater in the Thompson simulation than the WSM6 simulation. The same holds true for all the other five micro-physics simulations. Table 4 shows the square of the dry (upper row) and moist (lower row) Brunt-Väisälä frequency $\left(\mathrm{N}^{2}\right)$ at, and above, mountain height at point $\mathrm{BV}$ along cross-section $\mathrm{AB}$. The upslope wind speed along crosssection $A B$ is similar in all simulations, regardless of what micro-physics scheme is used (not shown). The near surface wind speed is high (typically $25-30 \mathrm{~ms}^{-1}$ ) but decreases with height. At mountain height (i.e. $800 \mathrm{hPa}$ ) the wind speed is between 8 and $10 \mathrm{~ms}^{-1}$ and is reduced to zero between 650 and $700 \mathrm{hPa}$.

\subsection{Impact of moisture on the WRF/MYJ simulations}

In order to investigate whether evaporation, and consequently condensation, might be a relevant factor for the flow dynamics a "dry" simulation was carried out. This experiment was identical to the control simulation, (called WRF/MYJ), with the exception that the micro-physics and surface fluxes were turned off.

The simulated "dry" surface flow, on the lee side of Mt. Öræfajökull (location SKAFT), is considerably stronger then in the control simulation (WRF/MYJ) with full microphysics and surface fluxes (cf. Fig. 13, left). The lee side surface temperature is however on average two to five degrees lower than the control run temperature (cf. Fig. 13, right) during the storm, while it becomes similar at the end of it.

The cross section shown in Fig. 14 reveals greater wave activity and more intence turbulence above the lee side slopes of the mountain than in the control simulation. The stability immediately upslope of Mt. Öræfajökull is considerably less than in the control simulation, although the stability is similar at point $\mathrm{BV}$, as shown in Table 4. This leads to a weaker blocking in the "dry" simulation than in the control run.

\section{Discussions}

\subsection{Sensitivity to boundary layer parameterization}

The major difference between the MM5 and WRF simulations is in the wave breaking. In the MM5 simulations, there is greater dissipation in the mountain wave associated with greater TKE production below $600 \mathrm{hPa}$ at all times than there is in the WRF simulations. In the WRF simulations, the dissipation takes mainly place between 950 and $700 \mathrm{hPa}$. After 03:00 UTC, 16 September, it is confined between the surface and $800 \mathrm{hPa}$. The difference in the intensity of the simulated downslope winds can be explained by less dissipation associated with turbulence in the WRF simulations than in the MM5 simulations. Since upper air observations are not available to verify the simulated wave breaking, the accuracy of the simulated surface winds and temperature is the only measurable performance of both the MM5 and WRF models for this windstorm event.

The two different boundary layer scheme perform similarily within the WRF model, and the greatest difference is found aloft. The 2EQ model gives stronger wave activity but slightly weaker sub-grid turbulence. Without observations aloft, it can not be determined which PBL scheme performs better. 


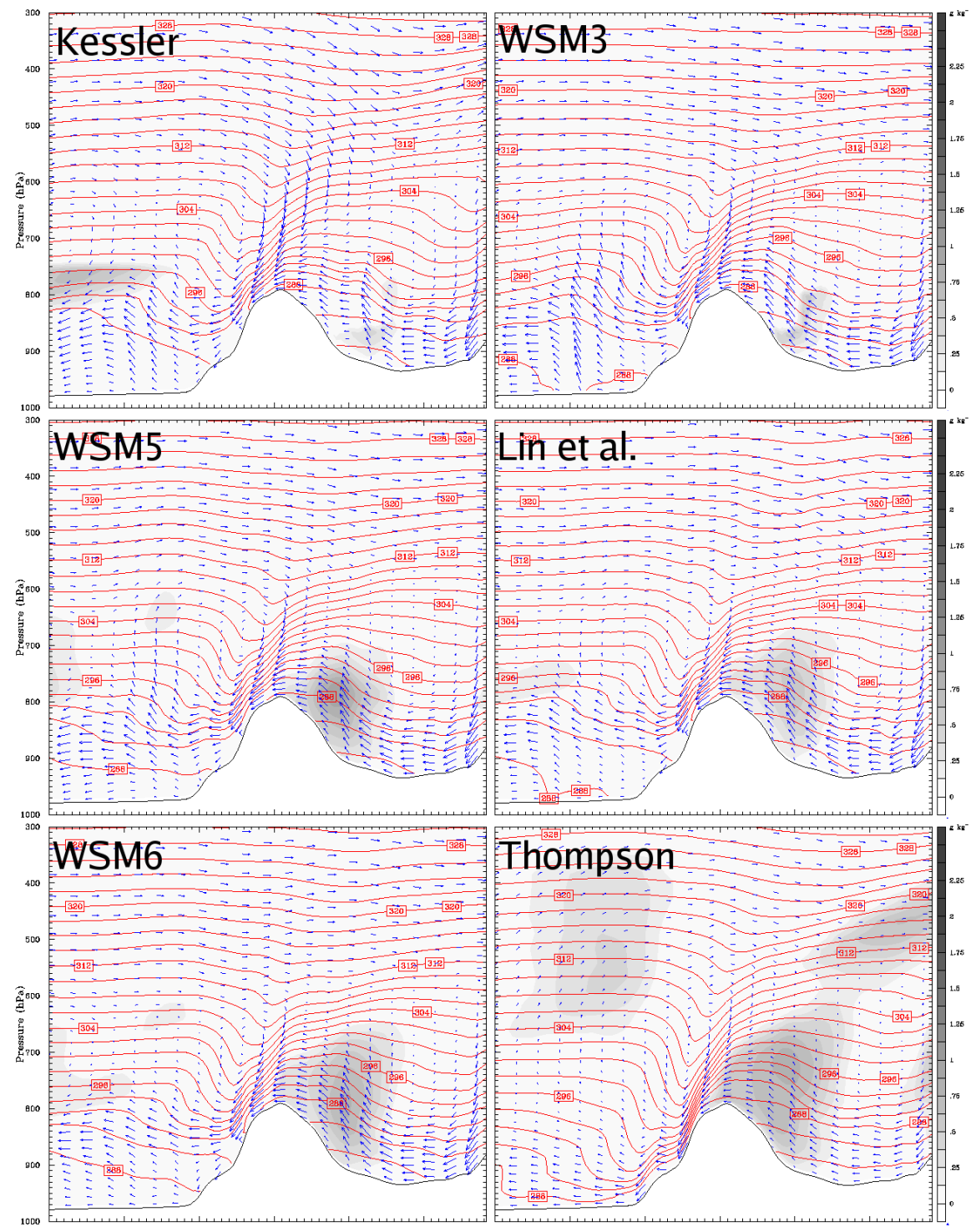

Fig. 9. Cross section along line $\mathrm{AB}$ (cf. Fig. 4) showing potential temperature (red lines) [K], wind along cross section (blue arrows) [ms ${ }^{-1}$ ] and cloud water mixing ratio $[\mathrm{g} / \mathrm{kg}]$ at 06:00 UTC 16 September 2004. micro-physics schemes are, from top left to bottom right: Kessler, WSM3, WSM5, Lin et al., WSM6 and Thompson.

\subsection{Sensitivity to micro-physics parameterization}

\subsubsection{Precipitation}

Different micro-physics schemes affect the simulated surface wind and temperature as well as the precipitation. The simulated precipitation in the simple Kessler scheme is similar to the simulated precipitation in the more complex WSM6, Lin et al. and Thompson schemes (cf. Fig. 7). For mountains of similar height as Mt. Öræfajökull this is in agreement with results in Miglietta and Rotunno (2006). Miglietta and Rotunno investigated moist, nearly neutral flow over a ridge in an idealistic framework. For a 700 meter high nar- row ridge (i.e. with halfwidth of $10 \mathrm{~km}$ ) the Kessler and Lin et al. schemes produced very different rain rates. The Kessler scheme had a lower rain rate and produced precipitation only on the upslope side of the ridge whilst the Lin et al. produced precipitation further upstream and had a distinct downslope maxima as well. The reason for this difference lies in a lower threshold used for autoconverting cloud water to rain in the Lin et al. scheme $\left(7 \times 10^{-4} \mathrm{gkg}^{-1}\right)$ to that of the Kessler shceme $\left(1 \times 10^{-3} \mathrm{gkg}^{-1}\right)$. The lower threshold values results in greater rainfall rate in the Lin et al. scheme and also in the upstream shift of the precipitation as the conversion of cloud water to rain occurs earlier. The downslope maxima in the Lin et al. scheme is generated by a downstream ice cloud 


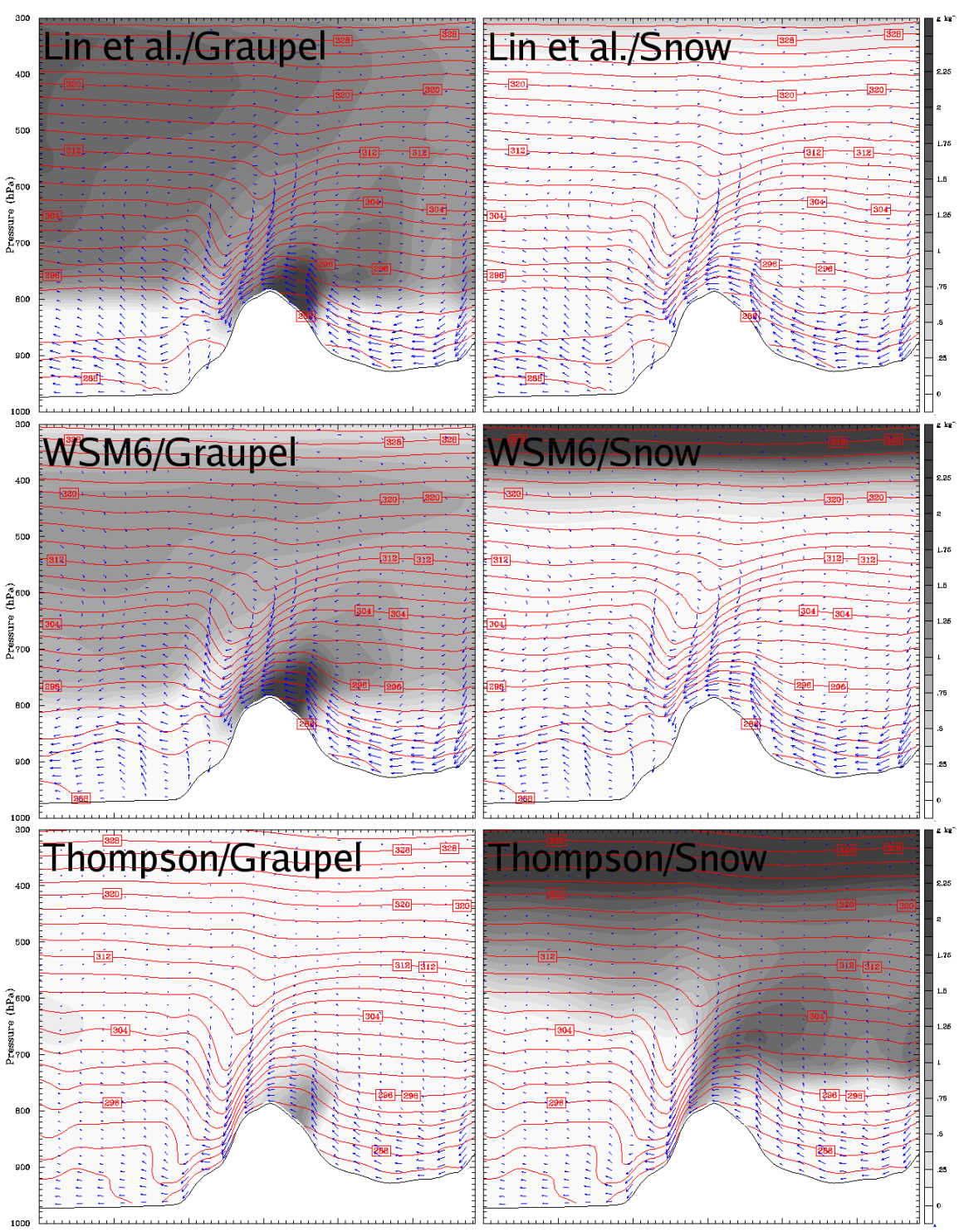

Fig. 10. Cross section along line $A B$ (cf. Fig. 4) showing potential temperature (red lines) [K], wind along cross section (blue arrows) [ms $\left.{ }^{-1}\right]$, graupel mixing ratio $[\mathrm{g} / \mathrm{kg}$ ] (left columns) and snow mixing ratio $[\mathrm{g} / \mathrm{kg}$ ] (right column) at 09:00 UTC 16 September 2004. micro-physics schemes are Lin et al. (top), WSM6 (middle) and Thompson (bottom).

and is the result of the ice microphysical processes that convert ice cloud to snow and then convert the snow to graupel. However, for the case of a higher $(2000 \mathrm{~m})$ ridge, i.e. similar to the hight of Mt. Öræfajökull, both schemes behave in a similar manner, the maximum precipitation is confined to the upstream side of the ridge with the Kessler scheme producing greater rainfall rate. The reason is that the more intense vertical motions due to a higher mountain results in much larger amounts of condensate than with a lower mountain. Consequently, the intensity and the location of the upwind precipitation maximum is not so dependent on the differing thresholds for autoconversion between the Lin et al. and
Kessler shcemes. The accumulated $15 \mathrm{~h}$ precipitation simulated on the upslope hill of Mt. Öræfajökull is in general of the same order as the maximum $24 \mathrm{~h}$ precipitation values that have been observed on lowland in this area. The maximum observed $24 \mathrm{~h}$ precipitation was at location KVISK on 9-10 January $2002(293.3 \mathrm{~mm})$. This is a clear indication that precipitation in the mountains can be much greater than at the foothills. 


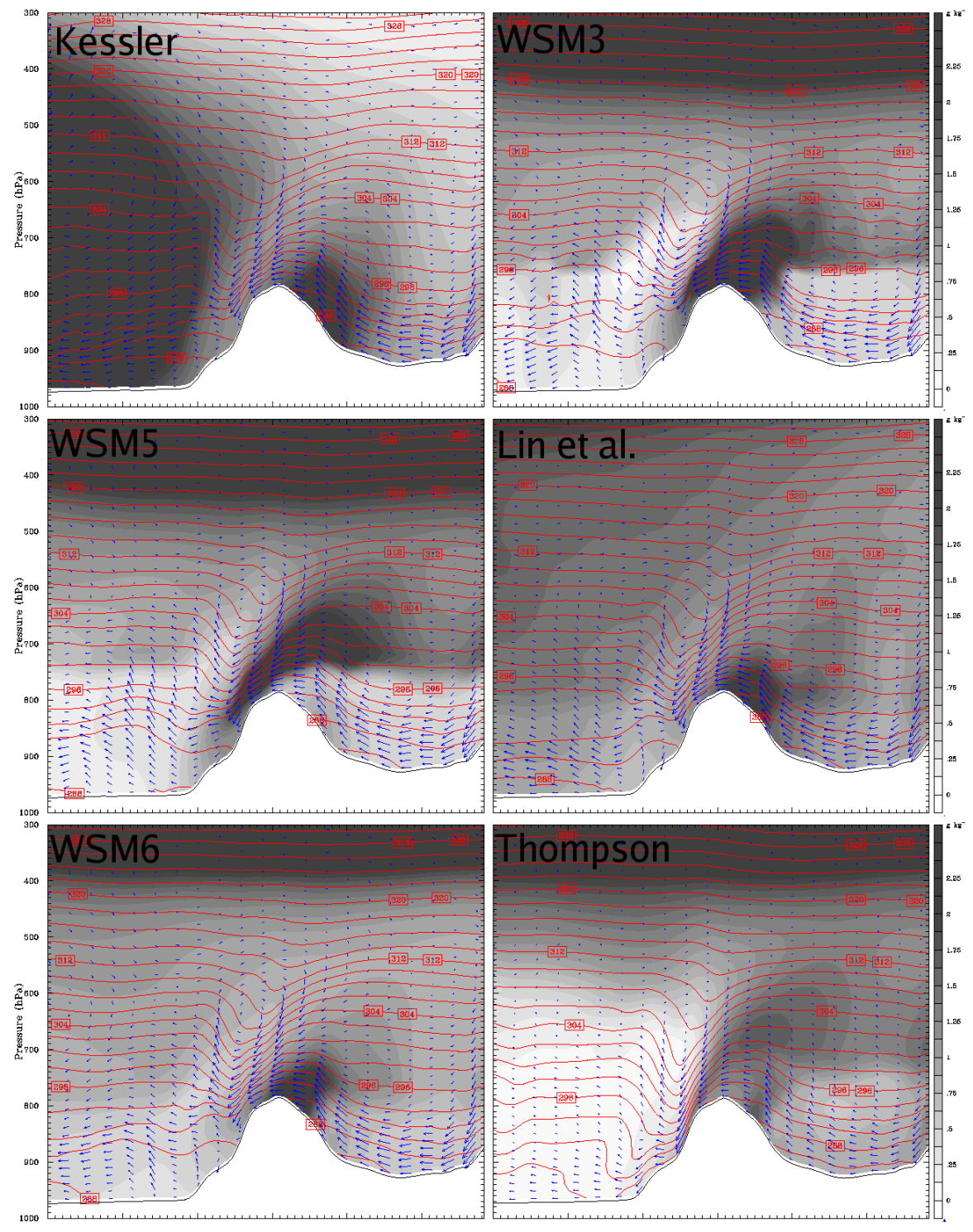

Fig. 11. Cross section along line $\mathrm{AB}$ (cf. Fig. 4) showing potential temperature (red lines) [K], wind along cross section (blue arrows) $\left[\mathrm{ms}^{-1}\right]$, and total precipitation mixing ratio $[\mathrm{g} / \mathrm{kg}]$ at 09:00 UTC 16 September 2004. micro-physics schemes are, from top left to bottom right: Kessler, WSM3, WSM5, Lin et al., WSM6 and Thompson.

\subsubsection{Upstream stability}

Simulations done with WRF/MYJ in combination with various cloud micro-physics schemes showed little variations in upslope wind-speed along cross-section $\mathrm{AB}$ (cf. Fig. 4). As the Froude ${ }^{2}$ number is a function of the characteristic mountain height, the upslope wind-speed and upslope stability, this emphasises the importance of capturing the upslope stability correctly in order to determine whether the flow will be able

\footnotetext{
${ }^{2}$ Traditionally, the Froude number is a measure of the ratio of inertial and buoyant forces, i.e. whether there is a flow-over or a flow-around an obstacle.
}

to cross the obstacle and cause a downslope wind storm. The upstream low-level flow at, and above, mountain top level (approx. between 700 and $800 \mathrm{hPa}$ ) in the Thompson scheme simulation (cf. Table 4) is noticably more stable than in the other runs. Conversely, the simulated upstream atmospheric stability below the mountain top level is slightly weaker with the Thompson scheme than with the other schemes. According to Smith (1985) greater upstream stability at mountain top level tends to produce stronger downslope winds. Furthermore, Smith et al. (2002) suggest that shallower upstream blocking contributes to stronger gravity wave activity than deeper blocking through a greater effective mountain height, 


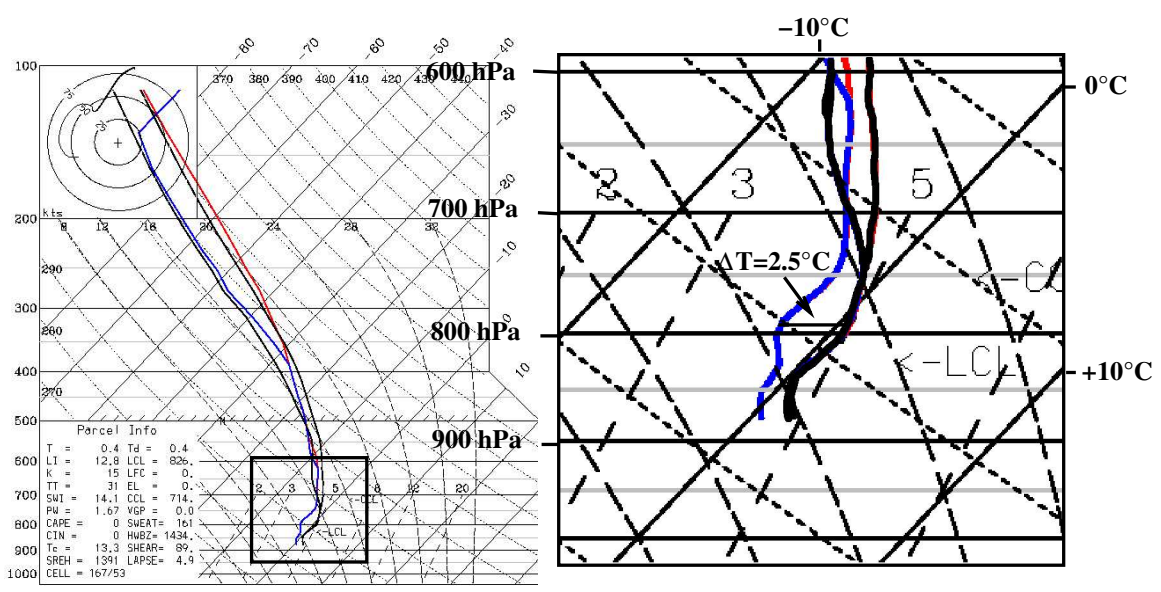

Fig. 12. Skew-T diagram at location B (cf. Fig. 4) at 06:00 UTC 16 September 2004, Thompson micro-physics scheme (blue and red lines) and the WSM6 scheme (black lines). The zoomed-in figure to the right shows that the maximum temperature difference $\left(2.5^{\circ}\right)$ between the two schemes is at approximately $800 \mathrm{hPa}$ height.

Table 4. The square of the simulated Brunt-Väisälä frequency $\left(\mathrm{N}^{2}\right)\left[\mathrm{s}^{-2}\right]$ at point BV on 16 September, 06:00 UTC at various pressure levels for all ten simulations. Here, $N$ is defined as $\sqrt{\frac{g}{\theta} \frac{\mathrm{d} \theta}{\mathrm{d} z}}$, where $\theta$ is the dry (upper row) and moist (lower row) equivelant potential temperature, $g$ is the local acceleration of gravity, and $z$ is geometric height.

\begin{tabular}{|c|c|c|c|c|c|}
\hline & $650-700 \mathrm{hPa}$ & $700-750 \mathrm{hPa}$ & $750-800 \mathrm{hPa}$ & $800-850 \mathrm{hPa}$ & $850-900 \mathrm{hPa}$ \\
\hline WRF/MYJ & $13.1 \times 10^{-5}$ & $17.8 \times 10^{-5}$ & $27.3 \times 10^{-5}$ & $38.8 \times 10^{-5}$ & $12.3 \times 10^{-5}$ \\
\hline Kessler & 0.0 & $15.0 \times 10^{-5}$ & $18.0 \times 10^{-5}$ & $64.0 \times 10^{-5}$ & 0.0 \\
\hline WRF/MYJ & $16.3 \times 10^{-5}$ & $17.7 \times 10^{-5}$ & $22.2 \times 10^{-5}$ & $29.2 \times 10^{-5}$ & $23.2 \times 10^{-5}$ \\
\hline WSM3 & 0.0 & 0.0 & $10.0 \times 10^{-5}$ & $18.2 \times 10^{-5}$ & $13.0 \times 10^{-5}$ \\
\hline WRF/MYJ & $15.6 \times 10^{-5}$ & $16.1 \times 10^{-5}$ & $25.2 \times 10^{-5}$ & $31.9 \times 10^{-5}$ & $21.2 \times 10^{-5}$ \\
\hline WSM5 & $3.6 \times 10^{-5}$ & $3.0 \times 10^{-5}$ & $13.0 \times 10^{-5}$ & $20.5 \times 10^{-5}$ & $9.6 \times 10^{-5}$ \\
\hline WRF/MYJ & $17.0 \times 10^{-5}$ & $15.9 \times 10^{-5}$ & $25.8 \times 10^{-5}$ & $34.3 \times 10^{-5}$ & $18.0 \times 10^{-5}$ \\
\hline Line et al. & 0.0 & $5.0 \times 10^{-5}$ & $24.0 \times 10^{-5}$ & $23.3 \times 10^{-5}$ & $13.5 \times 10^{-5}$ \\
\hline WRF/MYJ & $17.1 \times 10^{-5}$ & $16.2 \times 10^{-5}$ & $23.8 \times 10^{-5}$ & $36.0 \times 10^{-5}$ & $20.4 \times 10^{-5}$ \\
\hline WSM6 & 0.0 & $1.0 \times 10^{-5}$ & $12.0 \times 10^{-5}$ & $25.2 \times 10^{-5}$ & $8.5 \times 10^{-5}$ \\
\hline WRF/MYJ & $19.0 \times 10^{-5}$ & $19.4 \times 10^{-5}$ & $29.1 \times 10^{-5}$ & $30.8 \times 10^{-5}$ & $19.8 \times 10^{-5}$ \\
\hline Thompson & $10.0 \times 10^{-5}$ & $10.0 \times 10^{-5}$ & $120.0 \times 10^{-5}$ & 0.0 & 0.0 \\
\hline WRF/MYJ & $22.0 \times 10^{-5}$ & $17.6 \times 10^{-5}$ & $21.8 \times 10^{-5}$ & $26.6 \times 10^{-5}$ & $19.2 \times 10^{-5}$ \\
\hline Thompson dry & $11.8 \times 10^{-5}$ & $6.3 \times 10^{-5}$ & $10.2 \times 10^{-5}$ & $15.6 \times 10^{-5}$ & $7.2 \times 10^{-5}$ \\
\hline WRF/2EQ & $19.0 \times 10^{-5}$ & $19.4 \times 10^{-5}$ & $29.2 \times 10^{-5}$ & $31.2 \times 10^{-5}$ & $19.2 \times 10^{-5}$ \\
\hline Thompson & $6.0 \times 10^{-5}$ & $10.0 \times 10^{-5}$ & $80.0 \times 10^{-5}$ & 0.0 & 0.0 \\
\hline MM5/ETA & $18.5 \times 10^{-5}$ & $19.5 \times 10^{-5}$ & $23.1 \times 10^{-5}$ & $34.8 \times 10^{-5}$ & $18.0 \times 10^{-5}$ \\
\hline Reisner2 & 0.0 & 0.0 & 0.0 & $20.0 \times 10^{-5}$ & 0.0 \\
\hline MM5/2EQ & $18.6 \times 10^{-5}$ & $19.6 \times 10^{-5}$ & $23.2 \times 10^{-5}$ & $34.8 \times 10^{-5}$ & $18.2 \times 10^{-5}$ \\
\hline Reisner2 & 0.0 & 0.0 & 0.0 & $30.0 \times 10^{-5}$ & 0.0 \\
\hline
\end{tabular}



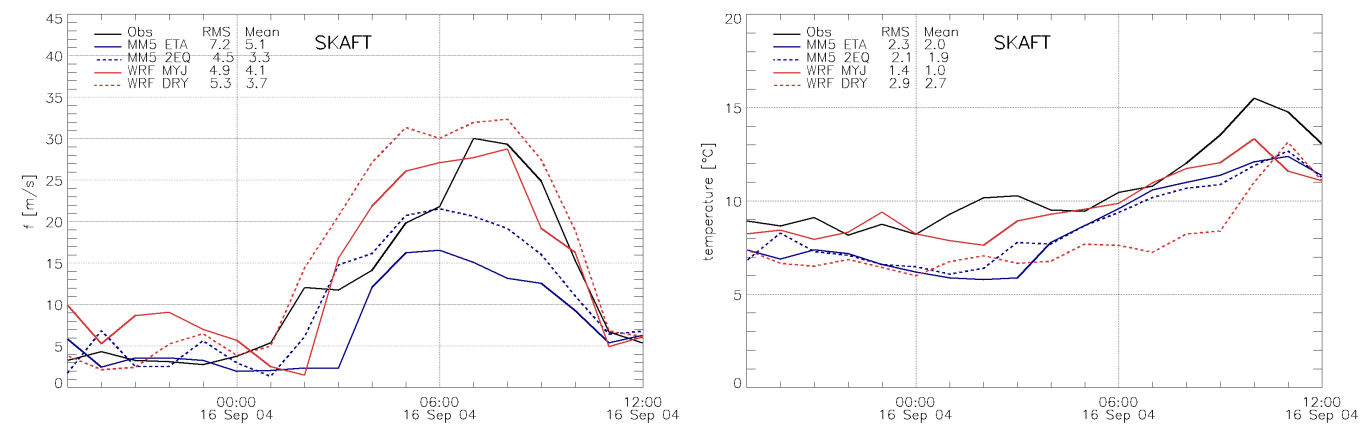

Fig. 13. Observed (solid black) and simulated (solid blue - MM5/ETA, blue dash - MM5/2EQ, solid red - WRF/MYJ, red dash - WRF/MYJ DRY) $10 \mathrm{~m}$ wind speed $\left[\mathrm{ms}^{-1}\right.$ ] (left) and 2-m temperature ${ }^{\circ}{ }^{\circ}$ (right) at station SKAFT (WMO\# 4172) in the lee of Mt. Öræfajökull.
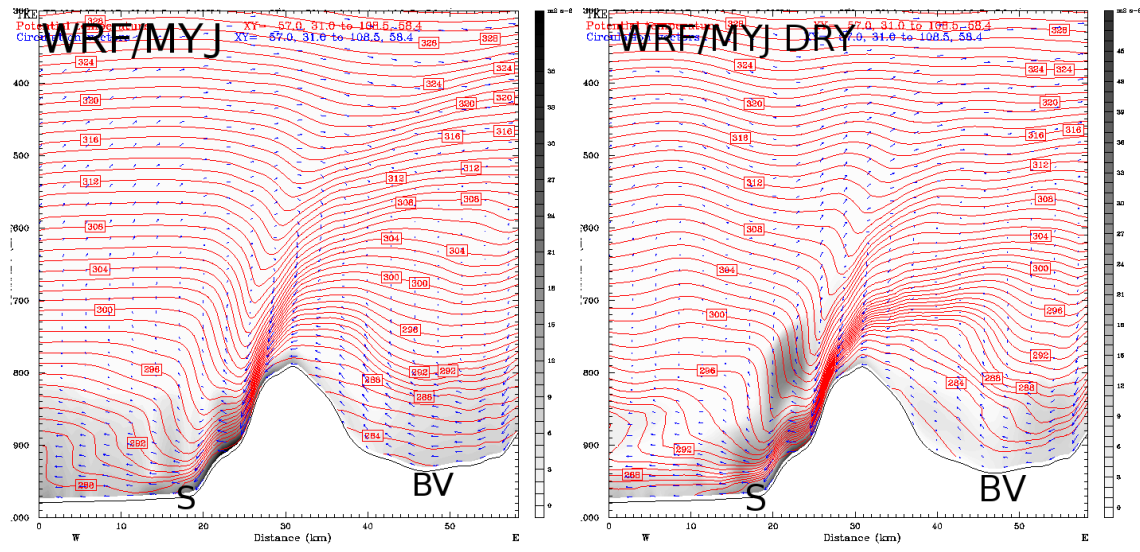

Fig. 14. Cross section along line $\mathrm{AB}$ (cf. Fig. 4) showing potential temperature (red lines) [K], wind along the cross section (blue arrows) $\left[\mathrm{ms}^{-1}\right]$ and turbulent kinetic energy (TKE) [J/kg] for WRF/MYJ (left) and WRF/MYJ DRY (right) at 16 September 2004, 06:00 UTC.

i.e. a larger part of the mountain is above the blocked flow. Jiang and Doyle (2009) use observations and simulations to reach a similar conclusion in their recent paper: firstly, that near surface moisture may enhance flow-topography interaction and lead to stronger waves through reducing the upslope blocking. Secondly, that moisture further aloft tends to dampen the wave activity through a destratification of the flow and lower buoyancy frequency. The simulated moisture distribution aloft is different for all the moisture-schemes discussed here so that these competing mechanisms have a different impact on the different simulations. In summary, a weakening of the wave activity leads to shorter downslope extent of the windstorms. Consequently a boundary layer separation occurs high on the lee slopes of the mountain in the flow simulated with all the schemes, except the Thompson scheme. Furthermore, the relatively dry downstream flow in the Thompson scheme is a result of less spillover and a greater dry-out of hydro-meteors.

\subsubsection{Role of hydro-meteors}

The observed sensitivity to cloud micro-physics schemes can be explained by the fact that various schemes produce different upslope distributions of precipitation and hydro-meteors, resulting in variation in the upslope static stability. Since the intensity of downslope wind is directly related to the intensity of the gravity-wave, which in turn is strongly dependent on the upslope static stability, this sensitivity is the manifestation of the great impact of the upslope precipitation on the downslope wind speed. The Thompson scheme proofed superior to the other five schemes tested in simulating the downslope windstorm. It is highly likely that this is related to the upward shift of the stable layer in the Thompson scheme (cf. Fig. 12). A possible explanation for this difference may be the different distribution function for graupel used in the Thompson scheme as well as differences in riming growth from the other micro-physics schemes. The greater formation of graupel in the Lin et al. and WSM6 schemes to that in the Thompson scheme (cf. Fig. 10) leads to more accretion (i.e. riming and/or depositional growth) which in turn 
leads to release of latent heat as liquid hydro-meteors are being turned into solid hydro-meteors. The Thompson scheme in contrast favours the formation of snow to that of graupel. Hence, there is less accretion and greater aggregation that takes place. As a result there is less release of latent heat than in the other two simulations and the region between 750 and $850 \mathrm{hPa}$ becomes colder (cf. Fig. 11) and more stable. Previous sensitivity tests, e.g. by Colle et al. (2005) have shown that orographically influenced precipitation is in fact greatly dependent on snowfall velocity and snow size distribution. Woods et al. (2007) investigated the sensitivity of the Thompson micro-physics scheme to the representation of snow particle types. They demonstrated the defectiveness of the conventional assumption of snow particles as spheres of constant density. A more realistic empirical mass-diameter relationship resulted in an increased number of particles and a shift of the snow size distribution towards larger particles. This in turn led to increased depositional growth of snow and decreased cloud water production.

\subsection{Sensitivity to atmospheric moisture}

Compared to the control simulation with the Thompson micro-physics scheme, the dry simulation produces a too fast surface flow in the lee of the mountain. This is due to stronger gravity wave activity aloft, which is explained by the weaker atmospheric stability immediately above the upstream slopes of the mountain. The weaker and shallower blocking increases the effective mountain height and the flow/mountain interaction is stronger (Smith et al., 2002).

Similarily, the leeside temperature deficit in the dry simulation is a result of the weaker blocking allowing potentially colder air to ascend over the mountain and descend down the leeside than in the control simulation.

When the leeside flow in the dry simulation is compared to the flow with the other moisture schemes than Thompson, it seems plausible that in addition to less favourable upslope condition for wave formation, some of the poor model performance in the lee may be accounted for by evaporative cooling of the excessive simulated precipitation. This should lead to cooling on the leeside, and increased stability at lowlevels, and hence weakens the downward penetration of the wave. This corresponds to the Kessler scheme, which gives both excessive precipitation and weak waves.

\section{Conclusions}

A severe windstorm downstream of Mt. Öræfajökull in Southeast Iceland is simulated on a grid of $1 \mathrm{~km}$ horizontal resolution by using the PSU/NCAR MM5 model and the Advanced Research WRF model. Both models are run with a new, two equation planetary boundary layer (PBL) scheme as well as the ETA/MYJ PBL schemes. The storm is also simulated using five other micro-physics schemes in com- bination with the MYJ PBL scheme in WRF, as well as a "dry" run. It is found that the predictability of the windstorm is strongly dependent on the parameterization schemes, with complicated interactions between the flow dynamics and different physics.

Both models capture gravity-wave formation over Mt. Öræfajökull, while the vertical structure of the lee wave differs between the two models and the PBL schemes. The simulated wave in the WRF model (using both the MYJ and the 2EQ schemes) is not as steep as in the MM5 simulations. The WRF simulated downslope winds, using the MYJ PBL scheme, are in good agreement with the strength of the observed downslope windstorm. When simulated using the new two equation scheme, surface winds are not as strong. On the contrary, the MM5 simulated surface winds, with the new two equation model, are in better agreement to observations than when using the ETA scheme. The simulated surface temperature in the WRF simulations is closer to the observations than simulated temperature in the MM5 simulations.

One of the first papers employing observational data from aloft to study the impact of moisture on gravity waves is by Jiang and Doyle (2009). They found that moisture aloft will generally weaken the wave activity while it is however dependent on both the thickness and location of the moist layer as well as wind speed near mountain top level. The current study reveals a sensitivity to cloud micro-physics that can be explained by the difference in the simulated moisture and hydro-meteors distribution. The micro-physics schemes tested here give different downslope winds and all schemes, excluding the Thompson scheme, underestimate the downslope windstorm. This is caused by different simulated stability upstream of the mountain. How general these results may be remains however unclear. This emphasises the importance of observing micro-physical properties in cases like this in order to improve our understanding of downslope windstorms, precipitation distribution and the flow pattern in general and our ability to predict them.

Furthermore, this study highlights some of the difficulties related to predicting severe downslope windstorms. The ensemble based study of Reinecke and Durran (2009) showed a strong dependence of the predictability to small-scale features in the synoptic flow. Here, merely changing a parameterization in the atmospheric model is decisive for a successful forecast. However, this study is not definite in giving the correct parameterization for downslope windstorm prediction, i.e. the 2EQ PBL and Thompson-schemes, which perform best here. Windstorms in other locations of the world and in other synoptic settings may be better represented by other parameterizations. In this light, simple ensemble prediction systems based on one or more atmospheric models employing different boundary layer and microphysics schemes may prove a valuable tool in short range severe downslope windstorm prediction. 
Given the lack of upper air observations for this downslope windstorm event and the limitation of a single-case study, the results from this study are not conclusive but provide valuable information for the setup of realtime numerical forecasting systems in complex topography.

Acknowledgements. This work is part of the RÁV-project which is funded in part by the Icelandic Research Fund (Rannsóknarsjóður Íslands), grant number 70271013, and the NORA funded project "Vejrtjeneste for søberedskab", grant number 550-025. The weather stations, from which data has been used in this study, belong to the Icelandic Meteorological Office, the Icelandic Road Administration and the Icelandic Maritime Administration. The authors thank Sara Michelson for reading over the manuscript.

Comments from two anonymous reviewers are acknowledged.

Edited by: H. Wernli

\section{References}

Ágústsson, H. and Ólafsson, H.: Simulating a severe windstorm in complex terrain, Meteorol. Z., 16, 99-110, 2007.

Ágústsson, H. and Ólafsson, H.: The bimodal downslope windstorms at Kvísker, Meteor. Atmos. Phys., doi: 10.1007/s00703-010-0075-y, http://dx.doi.org/10.1007/ s00703-010-0075-y, 2010.

Bao, J. W., Michelson, S. A., Kantha, L. H., and Brown, J. W.: Implementation of a Two-Equation Vertical Turbulent Mixing Scheme in a Mesoscale Atmospheric Model. NOAA Technical Memorandum OAR PSD-311, National Oceanic and Atmospheric Administration, Boulder, CO, 33 pp., 2008.

Belǔsić, D. and Klaić, Z. B.: Estimation of bora wind gusts using a limited area model, Tellus, 56A, 296-307, 2004.

Belǔsić, D., Pasarić, M., and Orlić, M.: Quasi-periodic bora gusts related to the structure of the troposphere, Q. J. Roy. Meteorol. Soc., 130, 1103-1121, 2004.

Colle, B. A., Garwert, M. F., Wolfe, J. B., Mass, C. F., and Woods, C. P.: The 13-14 December 2001 IMPROVE-2 Event. Part III: Simulated Microphysical Budgets and Sensitivity Studies, J. Atmos. Sci., 62, 3535-3558, 2005.

Doyle, J. D. and Shapiro, M. A.: A multi-scale simulation of an extreme downslope windstorm over complex topography, Meteor. Atmos. Phys., 74, 83-101, 2000.

Doyle, J. D., Durran, D. R., Chen, C., Colle, B. A., Georgelin, M., Grubišić, V., Hsu, W. R., Huang, C. Y., Landau, D., Lin, Y. L., Poulus, G. S., Sun, W. Y., Weber, D. B., Wurtele, M. G., and Xue, M.: An intercomparison of model-predicted wave breaking for the 11 January 1972 Boulder windstorm, Mon. Weather Rev., 128, 901-914, 2000.

Doyle, J. D., Shapiro, M. A., Jiang, Q. F., and Bartels, D. L.: Large-amplitude mountain wave breaking over Greenland, J. Atmos. Sci., 62, 3106-3126, 2005.

Dudhia, J.: Numerical study of convection observed during the winter monsoon experiment using a mesoscale two-dimensional model, J. Atmos. Sci., 46, 3077-3107, 1989.

Durran, D. R.: Mountain Waves and Downslope Winds, in: Atmospheric Processes Over Complex Terrain, edited by: Blumen, W., American Meteorological Society, Boston, 59-81, 1990.
Grell, G. A., Dudhia, J., and Stauffer, D. R.: A Description of the Fifth-Generation Penn State/NCAR Mesoscale Model (MM5). NCAR/TN-398+STR, National Center for Atmospheric Research, Boulder, CO, 107 pp., 1995.

Grønås, S. and Sandvik, A. D.: Numerical simulations of local winds over steep orography in the storm over North-Norway on 12 October 1996, J. Geophys. Res., 104, 9107-9120, 1999.

Grubišić, V., Doyle, J. D., Kuttner, J., Dirks, R., Cohn, S. A., Pan, L., Mobbs, S., Smith, R. B., Whiteman, C. D., Czyzyk, S., Vosper, S., Weissman, M., Haimov, S., De Wekker, S., and Chow, F. K.: The Terrain-induced Rotor Experiment: A field campaign overview including observational highlights, B. Am. Meteor. Soc., 89, 1513-1533, doi:10.1175/ 2008BAMS2487.1, http://journals.ametsoc.org/doi/abs/10.1175/ 2008BAMS2487.1, 2008.

Hack, J. J., Boville, B. P., Kiehl, J. T., Rasch, P. J., and Williamson, D. L.: Description of the NCAR Community Climate Model (CCM2) NCAR/TN-382+STR, National Center for Atmospheric Research, Boulder, CO, 120 pp., 1993.

Hong, S. Y. and Lim, J. O. J.: The WRF single-moment 6-class microphysics scheme (WSM6), J. Korean Meteor. Soc., 42, 129151, 2006.

Hong, S. Y., Dudhia, J., and Chen, S. H.: A revised approach to ice microphysical processes for the bulk parameterization of clouds and precipitation, Mon. Weather Rev., 132, 103-120, 2004.

Janjić, Z. I.: The step-mountain eta coordinate model: Further developements of the convection, viscous sublayer and turbulence closure schemes, Mon. Weather Rev., 122, 927-945, 1994.

Janjić, Z. I.: Nonsingular Implementation of the Mellor-Yamada Level 2.5 Scheme in the NCEP Meso model. Office Note \#437, National Center for Environmental Prediction, 2001.

Jiang, Q. and Doyle, J. D.: The impact of moisture on mountain waves during T-REX, Mon. Weather Rev., 137, 3888-3905, 2009.

Kessler, E.: On the distribution and continuity of water substance in atmospheric circulations, Meteor. Monogr., 32, Amer. Meteor. Soc., 84 pp., 1969.

Lin, Y. L., Farley, R. D., and Orville, H. D.: Bulk parameterization of the snow field in a cloud model, J. Appl. Meteor., 22, 10651092, 1983.

Mellor, G. L. and Yamada, T.: Development of a turbulence closure model for geophysical fluid problems, Rev. Geophys. Space Phys., 20, 851-875, 1982.

Miglietta, M. M. and Rotunno, R.: Further Results on Moist Neutral Flow over a Ridge, J. Atmos. Sci., 56, 2796-2810, 2006.

Mlawer, E. J., Taubman, S. J., Brown, P. D., Iacono, M. J., and Clough, S. A.: Radiative Transfer for Inhomogenious Atmosphere: RRTM, a validated correlated-K Model for the Longwave., J. Geophys. Res., 102(D14), 16663-16682, 1997.

Ólafsson, H. and Ágústsson, H.: Observational and numerical evidence of strong gravity wave breaking over Greenland, Institute for Meteorological Research ISBN 9979-9709-3-6, ÜtgáfufélagiðSlemba, Reykjavík, 2006.

Ólafsson, H. and Ágústsson, H.: The Freysnes downslope windstorm, Meteorol. Z., 16, 123-130, 2007.

Ólafsson, H. and Ágústsson, H.: Gravity wave breaking in easterly flow over Greenland and associated low level barrier- and reverse tip-jets, Meteor. Atmos. Phys., 104, 191-197, 2009.

Ólafsson, H., Jónasson, N., and Karlsdóttir, S.: Háupplausnar 
reikningar til almennrar spágerðar (HRAS), lokaskýrsla, Technical Report 06011, Veðurstofa Íslands, Reykjavík, available at: http://www.vedur.is/utgafa/discretionary $\{-\}\{\}\{\}$ greinargerdir/ March2006, 2006 (in Icelandic).

Reinecke, P. A. and Durran, D. R.: Initial condition sensitivities and the predictability of downslope winds, J. Atmos. Sci., 66, 34013418, doi:\{10.1175/2009JAS3023.1\}, 2009.

Rögnvaldsson, Ó. and Ólafsson, H.: A case study of the Icelandic through, Proc. Int. Conf. Alp. Meteorol. (ICAM), p. 4, 2003.

Sandvik, A. D. and Hartsveit, K.: Study of a downslope windstorm over Southern-Norway, Rjukan, 16 January 2000, Tech.Rep. 18, The Norwegian Meteorological Institute (met.no), 2005.

Skamarock, W. C., Klemp, J. B., Dudhia, J., Gill, D. O., Barker, D. M., Wang, W., and Powers, J. G.: A Description of the Advanced Research WRF Version 2. NCAR Technical Note, NCAR/TN-468+(STR), National Center for Atmospheric Research, Boulder, CO, 88 pp., 2005.
Smith, R. B.: On Severe Downslope Winds, J. Atmos. Sci., 42, 2597-2603, 1985.

Smith, R. B.: Aerial observations of the Yougoslavian bora, Atmos. Sci., 44, 269-297, 1987.

Smith, R., Skubis, S., Doyle, J., Broad, A., Kiemle, C., and Volkert, H.: Mountain waves over Mt. Blanc: Influence of stagnant boundary layer, J. Atmos. Sci., 59, 2073-2092, 2002.

Thompson, G., Rasmussen, R. M., and Manning, K.: Explicit Forecasts of Winter Precipitation Using an Improved Bulk Microphysics Scheme. Part I: Description and Sensitivity Analysis, Mon. Weather Rev., 132, 519-542, 2004.

Woods, C. P., Stoelinga, M. T., and Locatelli, J. D.: The IMPROVE-1 Storm of 1-2 February 2001. Part III: Sensitivity of a Mesoscale Model Simulation of the Representation of Snow Particle Types and Testing of a Bulk Microphysical Scheme with Snow Habit Prediction, J. Atmos. Sci., 64, 3927-3948, 2007. 